\title{
Sister chromatid exchanges in human lymphocytes treated with silica
}

\author{
J C Pairon, M C Jaurand, L Kheuang, X Janson, P Brochard, J Bignon
}

\begin{abstract}
The abilities of Min U Sil quartz or tridymite particles to induce sister chromatid exchanges (SCEs) in cultures of human lymphocytes plus monocytes or of human purified lymphocytes were investigated. With cultures of lymphocytes plus monocytes the level of SCEs was significantly enhanced after treatment with tridymite at the highest dose tested (50 $\left.\mu \mathrm{g} / \mathrm{cm}^{2}\right)$. No effect was observed with purified lymphocytes. Quartz did not give clear cut results. Complementary experiments with tridymite filtrates suggested that phagocytosis of tridymite particles by monocytes was a necessary step for the induction of SCEs in human lymphocytes.
\end{abstract}

Silica is a ubiquitous mineral, abundant in the earth crust. Its presence in the environment results from natural processes and anthropological activities and is widely encountered in many industrial sectors, especially mines and quarries, foundries, granite and stone industries, glass, and ceramics.

The carcinogenic potency of silica has recently been reviewed by the IARC ${ }^{1}$ : crystalline silica is classified in the 2A group (limited evidence but a high suspicion of carcinogenicity to man). To investigate the carcinogenic potency of silica several epidemiological studies have been carried out in workers exposed to silica with or without silicosis. The results have been contradictory, some showing an excess of lung cancer and some not. The main problem has been that most of the positive studies did not correctly take into account confounding factors, expecially tobacco..$^{2-10}$ In the studies that did take account of well known pulmonary carcinogens the results showed an increased risk of lung cancer. ${ }^{11-13}$ Numerous animal experiments have been perfor-

INSERM Unité 139, Hôpital Henri Mondor, 94010 Créteil, France

J C Pairon, M C Jaurand, L Kheuang, P Brochard, J Bignon

Laboratoire d'Etude des Particules Inhalées, 75013

Paris, France

$\mathrm{X}$ Janson med. Wagner et al induced malignant lymphomas in different strains of rats (Wistar, Agus, and PVG) when quartz, cristobalite, or tridymite were injected into the pleural or peritoneal cavities. ${ }^{14-16}$ Jaurand $e t$ al also observed this type of tumour after intrapleural injection of DQ 12 quartz into Sprague-Dawley rats. ${ }^{17}$ In addition, pulmonary epithelial tumours were induced in Fisher 344 rats after inhalation of Min U Sil quartz. ${ }^{18} 19$ Groth et al also observed epithelial tumours in Fisher rats when quartz was injected intratracheally. ${ }^{20}$ From the data obtained with experimental animals, the IARC experts concluded that crystalline silica was carcinogenic to

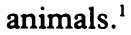

Since few in vitro studies have been carried out, ${ }^{21-24}$ the IARC's conclusions drawn from the results available were that there was inadequate evidence of carcinogenicity. ${ }^{1}$

The aim of the present work was to study the genotoxic effect of crystalline silica using human lymphocytes because of their easy availability.

\section{Material and methods \\ PARTICLES AND CHEMICALS}

Samples of Min U Sil 5 (a form of alpha quartz) and Tridymite 118 were obtained from the Centre d'Etudes et de Recherches des Charbonnages de France (CERCHAR); the mineralogical characteristics of this material are summarised in table 1.

Sources of chemicals were as follows: culture medium was RPMI 1640 from Biopro; fetal calf serum (FCS) was supplied by Flow laboratories; penicillin and streptomycin by Merieux: Lglutamine by Gibco; phosphate buffered saline (PBS) and lymphocytes separation medium (MSL 3000) by Eurobio; purified phytohaemaglutinine (PHA P), bromoxyuridine (BrdU), colcemid, and EDTA (disodium salt) by Sigma; heparin (Liquemine) by Roche; and potassium chromate $\left(\mathrm{K}_{2} \mathrm{CrO}_{4}\right)$, trisodium citrate, sodium chloride, ethanol, and glacial acetic acid by Prolabo.

\section{CELL PREPARATION}

Thirty millilitres of venous blood were aseptically taken with a syringe containing 1500 UI heparine from non-smoker young volunteer adults free of any medical treatment. An equal volume of PBS at $4^{\circ} \mathrm{C}$ was added and homogenisation was performed with a 
Table 1 Quartz and tridymite: mineralogical characteristics

\begin{tabular}{lll}
\hline Sample & Quartz Min U Sil 5 & Tridymite 118 \\
\hline Density & 2.65 & $2 \cdot 27$ \\
Particle size: & & \\
$<1 \mu \mathrm{m}$ & $56 \%$ & $87.9 \%$ \\
$1-2 \mu \mathrm{m}$ & $27.3 \%$ & $8.6 \%$ \\
$2-5 \mu \mathrm{m}$ & $15.7 \%$ & $3.35 \%$ \\
$>5 \mu \mathrm{m}$ & $1 \% \%$ & $0.15 \%$ \\
Particle concentration & 0.54 & 6.4 \\
(particle $\left.\times 10^{6} / \mu \mathrm{g}\right)$ & & \\
\hline
\end{tabular}

Pipet-Aid. The homogenate was centrifuged (15 min, $900 \times \mathrm{rpm}, 4^{\circ} \mathrm{C}$ ) and the supernatant removed. An equal volume of PBS was added to this platelet poor blood. Isolation of lymphocytes and monocytes (lymphocytes + monocytes) was carried out by differential centrifugation of $25 \mathrm{ml}$ of this mixture on $11 \mathrm{ml}$ of MSL $\left(26^{\prime} \mathrm{min}, 1700 \times \mathrm{rpm}, 20^{\circ} \mathrm{C}\right)$. Cells were rinsed twice with PBS (10 min, $1500 \times \mathrm{rpm}$, $4^{\circ} \mathrm{C}$ ), then suspended in RPMI 1640 supplemented with $10 \%$ FCS, $233 \mu \mathrm{g}$ L-glutamine, $50 \mu \mathrm{g} / \mathrm{ml}$ vitamin $\mathrm{C}, 200 \mu \mathrm{g} / \mathrm{ml}$ cysteine, $100 \mathrm{U} / \mathrm{ml}$ penicillin, and $50 \mu \mathrm{g} / \mathrm{ml}$ streptomycin.

Purification of lymphocytes was carried out by adhesion of monocytes on to plastic Falcon flasks. Cells were suspended in RPMI 1640 supplemented with $5 \%$ FCS at a concentration of $10^{6}$ cells $/ \mathrm{ml}$, then incubated at $37^{\circ} \mathrm{C}, 5 \% \mathrm{CO}_{2}$ for one hour. The suspension was harvested and centrifuged to obtain the purified lymphocytes. The residual percentage of monocytes was determined for each experiment before and after adhesion by means of MayGrunwald Giemsa staining of smears.

\section{PREPARATION OF PARTICLES}

Particles were sterilised by exposure to ultraviolet light for 12 hours and then suspended at a concentration of $1 \mathrm{mg} / \mathrm{ml}$ in RPMI 1640 and dispersed by sonication for 10 minutes $(20 \mathrm{kHz}, 20 \mathrm{w})$.

"Tridymite filtrates" were prepared as follows: $2 \mathrm{mg}$ of tridymite were suspended in $1 \mathrm{ml}$ of RPMI 1640 supplemented with $10 \%$ FCS (FCS + ) or without FCS (FCS -). These suspensions were sonicated for 10 minutes $(20 \mathrm{kHz}, 20 \mathrm{w})$, incubated for 48 hours $\left(37^{\circ} \mathrm{C}, 5 \% \mathrm{CO}_{2}\right)$, and then filtered through a Millipore filter of porosity $0 \cdot 2 \mu \mathrm{m}$.

$\mathrm{K}_{2} \mathrm{CrO}_{4}$ was solubilised at $1 \mathrm{mg} / \mathrm{ml}$ in RPMI 1640 and filtered (Millipore $0.2 \mu \mathrm{m}$ ).

\section{TREATMENT OF CELLS}

Cells were cultured in multiwell plates $\left(2 \mathrm{~cm}^{2} /\right.$ well). One million cells in $1 \mathrm{ml}$ were incubated in each well. Cells were stimulated with $12.5 \mu \mathrm{g} / \mathrm{ml}$ PHA P and $\mathrm{BrdU}$ was added at the beginning of the culture (final concentration: $10 \mu \mathrm{g} / \mathrm{ml}$ ). Lymphocytes + monocytes or purified lymphocytes were treated with different concentrations of particles (1-10-100 $\mu \mathrm{g} /$ $\mathrm{ml}$ for lymphocytes + monocytes, 50 and $100 \mu \mathrm{g} / \mathrm{ml}$ for purified lymphocytes). Because of the sedimentation of particles these concentrations are equivalent to $0 \cdot 5-5-50$ and $25-50 \mu \mathrm{g} / \mathrm{cm}^{2}$ respectively. Lymphocytes + monocytes were also treated with $100 \mu \mathrm{l}$ of tridymite filtrates. Multiwell plates were then incubated $\left(37^{\circ} \mathrm{C}, 5 \% \mathrm{CO}_{2}\right)$ for 67 hours, corresponding to about two cell cycles. Potassium chromate was added after 24 hours (final concentration of $0.5 \mu \mathrm{g} / \mathrm{ml})$.

\section{CHROMOSOME PREPARATION AND STAINING}

Chromosome preparation was performed according to the method of Dutrillaux and Couturier. ${ }^{25} \mathrm{Col}-$ cemid was added during the last two hours of incubation at the final concentration of $0.30 \mu \mathrm{g} / \mathrm{ml}$. Cells were then harvested using $0.02 \%$ EDTA disodium salt in PBS and centrifuged at $1500 \times \mathrm{rpm}$ for seven minutes. The cells were treated at $37^{\circ} \mathrm{C}$ with $0.075 \mathrm{M} \mathrm{KCl}$ for 35 minutes then fixed twice with ethanol: glacial acetic acid $(3: 1)$ at $+4^{\circ} \mathrm{C}$. Spreading was made one day later. Slides were stained with $5 \mu \mathrm{g} / \mathrm{ml}$ Hoechst 33258 in PBS, exposed to ultraviolet light for 30 minutes in a thin strip of PBS, incubated in $2 \mathrm{X}$ super concentrated solution ( $0.3 \mathrm{M}$ sodium chloride, $0.03 \mathrm{M}$ trisodium citrate) at $60^{\circ} \mathrm{C}$ for 20 minutes, and finally stained with $3 \%$ Giemsa for 10 minutes.

\section{CYTOTOXICITY STUDY AND ELECTRON}

MICROSCOPY STUDY

Cytotoxicity was evaluated using Trypan blue staining. Cells were harvested after 24 hours of culture and then stained according to standard methods. The mean survival percentage was calculated from three wells of each treatment.

Two experiments were performed under electron microscopy to study phagocytosis of the particles by the cells, one with lymphocytes + monocytes and one with purified lymphocytes. The method used has been described elsewhere. ${ }^{26}$

\section{SCORING AND STATISTICAL ANALYSIS}

Two hundred metaphases were studied to evaluate the cell cycle kinetics according to the formula of Sinha et $\mathrm{l}^{7}$ : average lymphocytic divisions $(\mathrm{ALD})=$ $(1 \times$ I $)+(2 \times$ II $)+(3 \times$ III $)$, where I, II, and III are the proportions of metaphases of first, second, and third (or more) cycles.

Forty metaphases in the second cycle having 44-48 chromosomes per metaphase were scored. The results were expressed as number of sister chromatid exchanges (SCEs) per metaphase. The MannWhitney test was applied to compare the results obtained in untreated and treated cells. 
Table 2 SCEs in lymphocytes + monocytes treated with silica particles

\begin{tabular}{|c|c|c|c|c|c|c|c|c|c|}
\hline \multirow{3}{*}{\multicolumn{2}{|c|}{$\begin{array}{l}\text { Experiment No } \\
\text { Treatment }\left(\mu \mathrm{g} / \mathrm{cm}^{2}\right)\end{array}$}} & \multicolumn{8}{|c|}{ SCEs per metaphase } \\
\hline & & \multicolumn{2}{|l|}{1} & \multicolumn{2}{|l|}{2} & \multicolumn{2}{|l|}{3} & \multicolumn{2}{|l|}{4} \\
\hline & & (a) & $p<(b)$ & (a) & $p<(b)$ & (a) & $p<(b)$ & (a) & $p<(b)$ \\
\hline Control & & $7 \cdot 2 \pm 2 \cdot 8$ & - & $8 \cdot 1 \pm 3 \cdot 4$ & - & $7 \cdot 7 \pm 2 \cdot 9$ & - & $8 \cdot 0 \pm 2 \cdot 9$ & - \\
\hline Quartz & $\begin{array}{r}0.5 \\
5.0 \\
50.0\end{array}$ & $\begin{array}{l}7 \cdot 1 \pm 2 \cdot 8 \\
7 \cdot 8 \pm 3 \cdot 1 \\
8 \cdot 0 \pm 3 \cdot 1\end{array}$ & $\begin{array}{l}\text { NS } \\
\text { NS } \\
\text { NS }\end{array}$ & $\begin{array}{r}8 \cdot 4 \pm 2 \cdot 9 \\
9 \cdot 1 \pm 3 \cdot 2 \\
10 \cdot 4 \pm 4 \cdot 5\end{array}$ & $\begin{array}{l}\text { NS } \\
\text { NS } \\
0 \cdot 05\end{array}$ & $\begin{array}{l}7.4 \pm 2.4 \\
7.5 \pm 2.5 \\
\text { (c) }\end{array}$ & $\begin{array}{l}\text { NS } \\
\text { NS } \\
\text { (c) }\end{array}$ & $\begin{array}{l}\overline{7} \cdot 4 \pm 2 \cdot 4 \\
8 \cdot 4 \pm 2 \cdot 7\end{array}$ & $\begin{array}{l}\overline{N S} \\
\text { NS }\end{array}$ \\
\hline Tridymite & $\begin{array}{r}0.5 \\
5.0 \\
50.0\end{array}$ & $\bar{z}$ & $\bar{z}$ & $\begin{array}{l}9 \cdot 6 \pm 3 \cdot 7 \\
9 \cdot 1 \pm 2 \cdot 8 \\
9 \cdot 7 \pm 3 \cdot 3\end{array}$ & $\begin{array}{l}\text { NS } \\
\text { NS } \\
0.05\end{array}$ & $\begin{array}{l}8 \cdot 0 \pm 3 \cdot 4 \\
9 \cdot 1 \pm 2 \cdot 6 \\
9 \cdot 5 \pm 3 \cdot 0\end{array}$ & $\begin{array}{l}\text { NS } \\
0.05 \\
0.05\end{array}$ & $\overline{\bar{I}}_{9 \cdot 4+2 \cdot 6}$ & $\overline{\bar{c}}$ \\
\hline $\mathrm{K}_{2} \mathrm{CrO}_{4}(0.5$ & & $20 \cdot 1+5 \cdot 1$ & 0.001 & $17.5 \pm 3.7$ & 0.001 & $22 \cdot 1 \pm 5 \cdot 9$ & 0.001 & $14 \cdot 8 \pm 3 \cdot 7$ & 0.001 \\
\hline
\end{tabular}

(a) $=$ Values represent mean $\pm S D$ on 40 metaphases.

(b) = Mann-Whitney test compares control at each particle concentration.

(c) = SCE quantitation could not be determined in this experiment because of lack of cells in second cycle.

\section{Results}

The results of silica induction of SCEs on lymphocytes + monocytes and purified lymphocytes are presented in tables 2 and 3 . In lymphocytes + monocytes the level of SCEs was enhanced with $50 \mu \mathrm{g} / \mathrm{cm}^{2}$ of tridymite in the three experiments and in one experiment at the intermediate dose $(5 \mu \mathrm{g} /$ $\left.\mathrm{cm}^{2}\right)$. Quartz only once induced a significant increase at the highest dose. By contrast, quartz and tridymite did not increase the number of SCEs per metaphase

Table 3 SCEs in purified lymphocytes treated with silica particles

\begin{tabular}{|c|c|c|c|c|c|}
\hline \multirow{3}{*}{\multicolumn{2}{|c|}{$\begin{array}{l}\text { Experiment no } \\
\text { Treatment }\left(\mu \mathrm{g} / \mathrm{cm}^{2}\right)\end{array}$}} & \multicolumn{4}{|c|}{ SCEs per metaphase } \\
\hline & & \multicolumn{2}{|l|}{5} & \multicolumn{2}{|l|}{6} \\
\hline & & (a) & $p<(b)$ & (a) & $p<(b)$ \\
\hline $\begin{array}{l}\text { Control } \\
\text { Quartz } \\
\text { Tridymite } \\
\mathrm{K}_{2} \mathrm{CrO}_{4} \\
\quad(0.5 \mu \mathrm{g} / \mathrm{ml})\end{array}$ & $\begin{array}{l}25 \\
50 \\
25 \\
50\end{array}$ & $\begin{array}{r}8 \cdot 2 \pm 2 \cdot 6 \\
7 \cdot 8 \pm 3 \cdot 2 \\
8 \cdot 0 \pm 2 \cdot 8 \\
8 \cdot 5 \pm 2 \cdot 7 \\
8 \cdot 9 \pm 3 \cdot 5 \\
13 \cdot 1 \pm 3 \cdot 3\end{array}$ & $\begin{array}{l}\overline{N S} \\
\text { NS } \\
\text { NS } \\
\text { NS } \\
0.001\end{array}$ & $\begin{array}{r}7 \cdot 8 \pm 2.5 \\
7 \cdot 1 \pm 2.0 \\
7 \cdot 7 \pm 2 \cdot 1 \\
7 \cdot 6 \pm 2.5 \\
8.6 \pm 3.6 \\
13.6 \pm 3.9\end{array}$ & $\begin{array}{l}\overline{N S} \\
\text { NS } \\
\text { NS } \\
\text { NS } \\
0.001\end{array}$ \\
\hline
\end{tabular}

(a) $=$ Values represent mean $\pm S D$ in 40 metaphases.

(b) = Mann-Whitney test compares control at each particle concentration. in purified lymphocytes. Control of the purification of lymphocytes gave the following results: the percentage of monocytes decreased from $30 \%$ to $1 \%$ after adhesion in experiment number 5 and from $50 \%$ to $2 \%$ in experiment number 6 .

Table 4 shows the results obtained with "tridymite filtrates." These three experiments (Nos 7, 8, and 9) were performed to confirm that the induction of SCEs in lymphocytes resulted from an interaction of lymphocytes and monocytes with tridymite particles but not from soluble compounds released in the culture medium by tridymite; there was no increase in the SCEs level with tridymite filtrates.

A significant increase in SCEs was obtained with cells treated with $\mathrm{K}_{2} \mathrm{CrO}_{4}$ in all experiments.

The ALD index decreased in cells treated with $\mathrm{K}_{2} \mathrm{CrO}_{4}$ when compared with control cells and was also lowered with particles most constantly with the highest concentrations (fig 1).

Results of the cytotoxicity studies are reported in table 5. With lymphocytes + monocytes there was a moderate decrease in the percentage of survival cells at 24 hours when cells were treated with the highest dose of silica. This decrease was more pronounced with quartz than with tridymite.

No silica particles were seen in sections of purified

Table 4 SCEs in lymphocytes + monocytes treated with tridymite filtrates

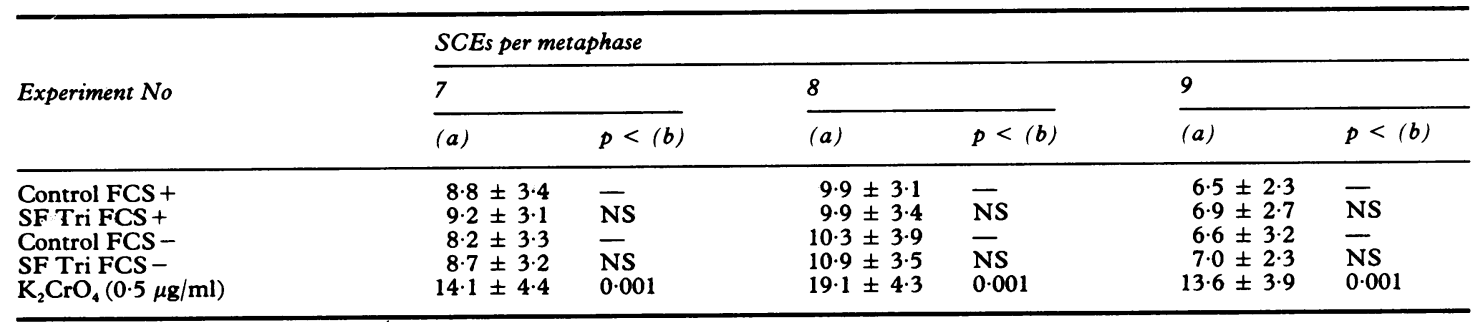

SF: Silica filtrate.

Tri: Tridymite.

FCS: Fetal calf serum.

(a) $=$ Values represent mean \pm SD on 40 metaphases.

(b) = Mann-Whitney test compares control at each particle concentration. 


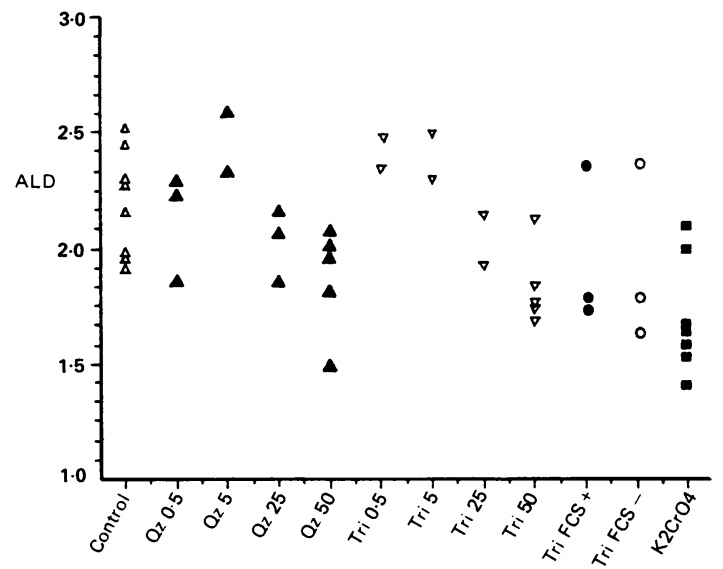

Figure 1 Average lymphocytic divisions ( $A L D$ ) index according to treatment in experiments with lymphocytes + monocytes and with purified lymphocytes.

lymphocytes by electron microscopy (fig 2). By contrast, sections of cultures from lymphocytes + monocytes showed evidence of phagocytosis by monocytes (fig 3 ) and quartz and tridymite were found in sections of these cells.

\section{Discussion}

Few experiments have been carried out to study the cytogenetic effects of crystalline silica. Price Jones $e t$ al found no increase in SCEs in V79-4 Chinese hamster cells treated with Min-U-Sil quartz. ${ }^{21}$
Table 5 Cytotoxicity of silica on lymphocytes + monocytes

\begin{tabular}{lrrr}
\hline & \multicolumn{2}{c}{$\%$ Survival at 24 hours } \\
\cline { 3 - 4 } Treatment & & Experiment $A$ & Experiment $B$ \\
\hline Control & & $93.7 \pm 3.8$ & $77.3 \pm 2.0$ \\
$\mathrm{~K}_{2} \mathrm{CrO}_{4}$ & $0.5 \mu \mathrm{g} / \mathrm{ml}$ & $74.3 \pm 3.8$ & $77.0 \pm 3.3$ \\
Quartz & $0.5 \mu \mathrm{g} / \mathrm{cm}^{2}$ & $73.7 \pm 7.4$ & $76.7 \pm 4.5$ \\
Quartz & $5.0 \mu \mathrm{g} / \mathrm{cm}^{2}$ & $70.0 \pm 0.8$ & -7.7 \\
Quartz & $50.0 \mu \mathrm{g} / \mathrm{cm}^{2}$ & $54.7 \pm 4.9$ & $54.7 \pm 6.3$ \\
Tridymite & $0.5 \mu \mathrm{g} / \mathrm{cm}^{2}$ & $72.3 \pm 6.1$ & $70.7 \pm 3.7$ \\
Tridymite & $5.0 \mu \mathrm{g} / \mathrm{cm}^{2}$ & $69.3 \pm 3.8$ & $74.0 \pm 4.6$ \\
Tridymite & $50.0 \mu \mathrm{g} / \mathrm{cm}^{2}$ & $58.0 \pm 1.6$ & $68.0 \pm 12.3$ \\
\hline
\end{tabular}

$\star$ Results are expressed as mean $\pm S D$.

Oshimura et al reported absence of chromosomal aberrations or cellular transformation after treatment of Syrian hamster embryo (SHE) cells with alphaquartz, ${ }^{22}$ whereas Hesterberg et al reported that treatment of SHE cells with Min-U-Sil quartz and alpha-quartz resulted in cell tranformation and induction of micronucleus. ${ }^{2324}$ Our data indicated that tridymite and quartz did not induce SCEs in purified lymphocytes. In their experiments Hesterberg et al noticed that silica particles were internalised and suspected a genotoxic action because of the direct interaction of silica with genetic material during mitosis. ${ }^{24}$ Our electron microscopic studies showed that there was no phagocytosis by purified lymphocytes and this could explain the absence of SCE induction in these cells after purification.

A significant increase in SCE level was observed when lymphocytes + monocytes were treated with tridymite but quartz did not give clear cut results. In

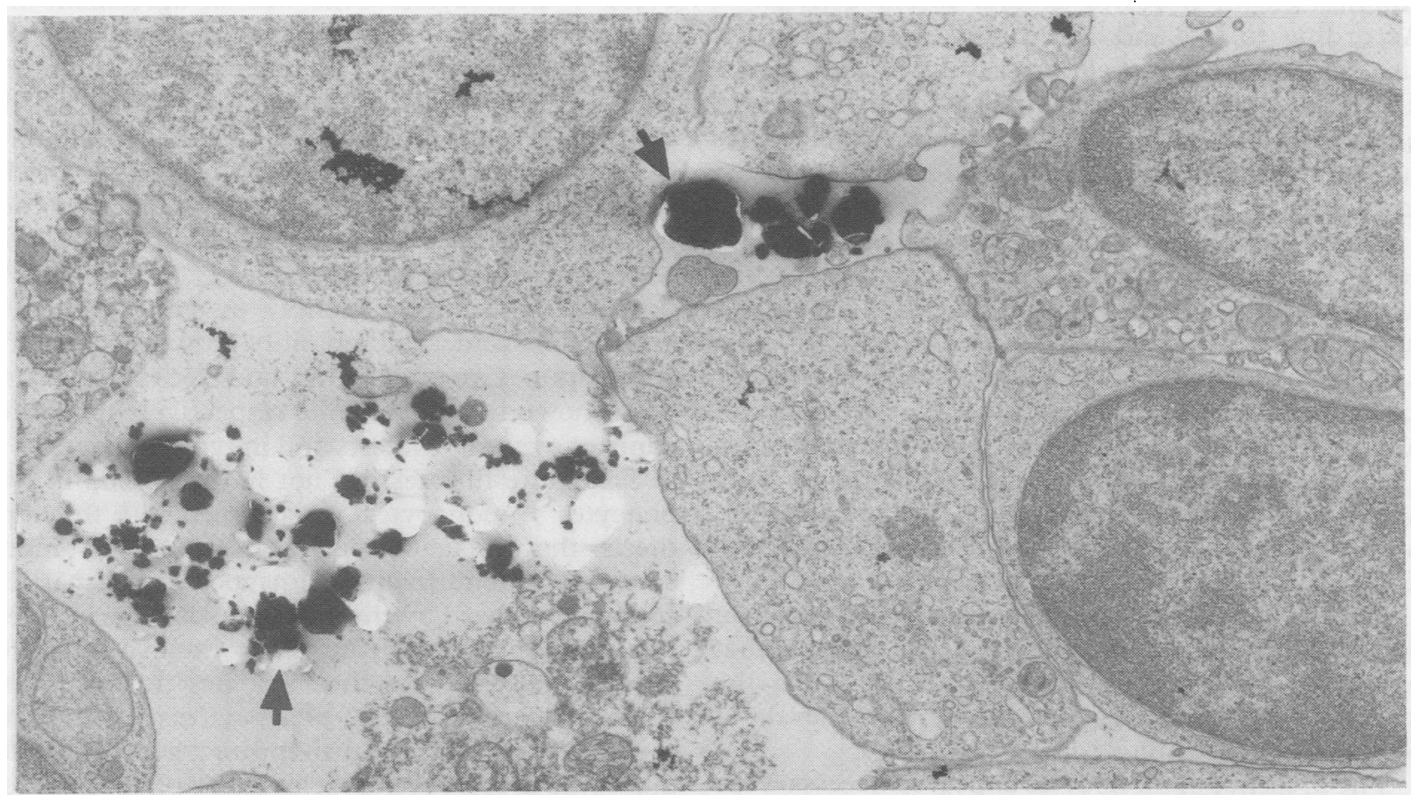

Figure 2 Electron microscopy of purified lymphocytes treated with tridymite. Several tridymite particles (arrows) are seen outside cells $(\times 9100)$. 


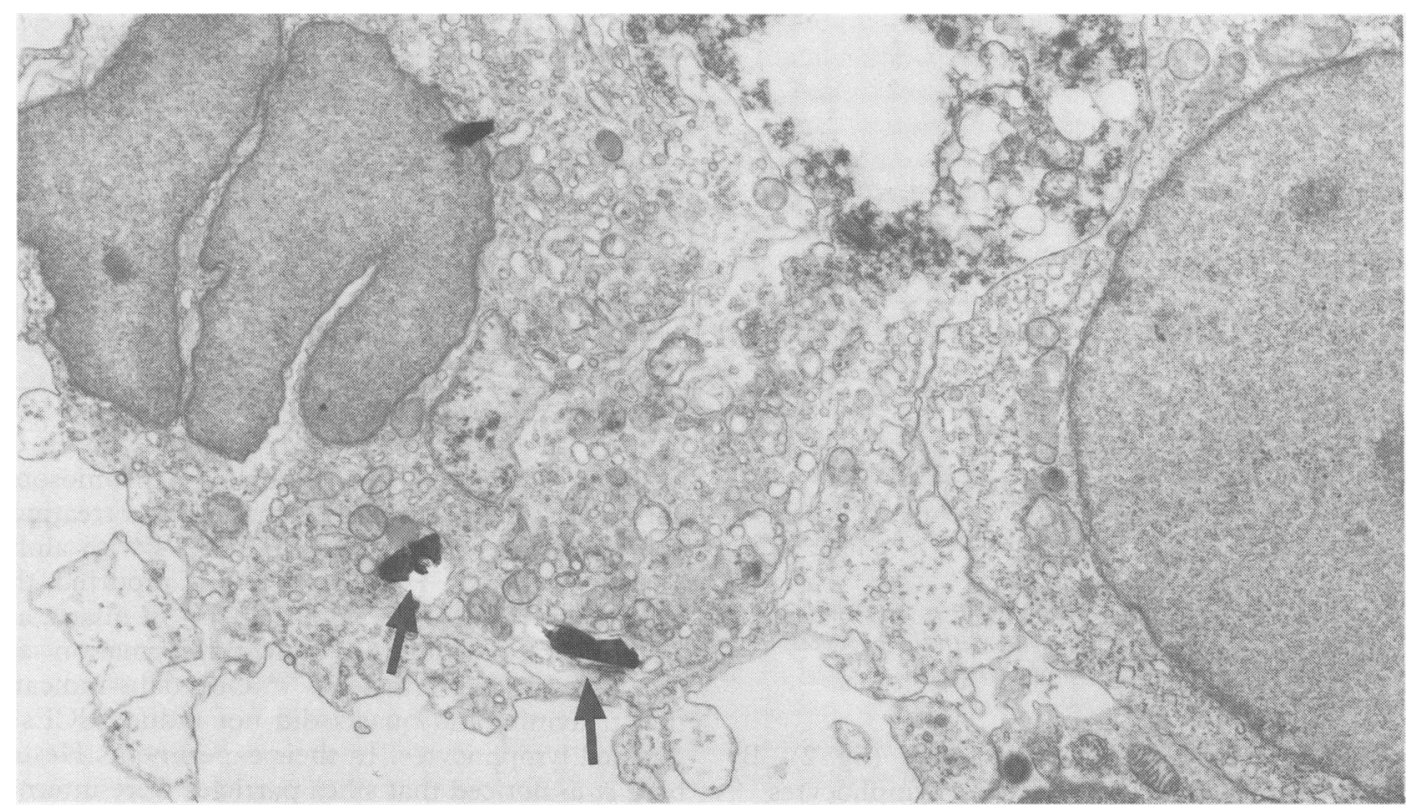

Figure 3 Electron microscopy of lymphocytes + monocytes treated with quartz. Quartz particles (arrows) are seen inside phagocytic vacuoles of a monocyte $(\times 7600)$.

addition to having a different crystalline structure, tridymite and quartz samples presented different granulometries: particle concentration per unit weight was about 12 times higher with tridymite than with quartz. The importance of particle size has been emphasised for fibres to explain carcinogenesis. ${ }^{28} 29$ According to Holland et al, silica induced fibrosis also depends on particle size and concentration. ${ }^{19}$ The higher number of tridymite particles than that of quartz and therefore the larger cumulated particles surface could explain the difference between tridymite and quartz.

When compared with the experiments of Price Jones $e t a l^{1}$ and Oshimura et al, ${ }^{22}$ our positive results with tridymite might be explained by the doses of particles used. These authors used $4 \mu \mathrm{g} / \mathrm{cm}^{2}$ and $2 \mu \mathrm{g} / \mathrm{cm}^{2}$ of quartz respectively whereas in our experiment significant SCE enhancement was observed with $50 \mu \mathrm{g} / \mathrm{cm}^{2}$. Hesterberg and Barrett observed a dose effect relation in transforming potency of quartz on SHE cells. ${ }^{23}$ They did not, however, obtain any significant cellular transformation with quartz doses lower than $10 \mu \mathrm{g} / \mathrm{cm}^{2}$. They also noticed that the dose effect relation was less than that obtained with chrysotile. Our data indicate that only the highest dose $\left(50 \mu \mathrm{g} / \mathrm{cm}^{2}\right)$ and once the medium dose $\left(5 \mu \mathrm{g} / \mathrm{cm}^{2}\right)$ led to increased levels of SCEs with tridymite.

The presence of monocytes appeared necessary for induction of SCEs in tridymite treated cells because positive results were observed with lymphocytes + monocytes but not with purified lymphocytes. The increase in the level of SCEs could not be due to the fact that observed metaphases belonged to monocytes because these cells do not proliferate in culture. Silica particles were slightly cytotoxic on lymphocytes + monocytes. This was in agreement with previous studies: silica is known to be cytotoxic towards macrophages $\mathrm{s}^{30-32}$ and not towards lymphocytes. ${ }^{31}$ Therefore a hypothesis could be suggested to explain the role of monocytes in the induction of SCEs in lymphocytes with silica particles. Phagocytosis of silica particles by monocytes could be followed by monocyte release of mediators. Monocytes are known to release interleukin $1{ }^{33}$ prostaglandins, leukotrienes, oxygen derivatives, arachidonic acid ${ }^{34}$ and possibly growth factors after stimulation. Growth factors ${ }^{35}$ and free radicals ${ }^{36}$ have been shown to induce SCEs respectively in Chinese hamster ovary fibroblasts and in lymphocytes.

Tridymite filtrates did not induce SCEs in lymphocytes + monocytes. This agreed with the hypothesis that phagocytosis is necessary to induce cytogenetic abnormalities. Phagocytosis of particles could be followed by chromosomal damage in at least two ways that are not mutually exclusive: a direct effect of particles on chromosomes during mitosis when cells are capable of phagocytosis, as suggested by Hesterberg $e t a^{24}$ and an indirect genetoxic effect that could involve factors released by phagocytic cells when the proliferative cells are not able to ingest particles. This was the case in our experiment. 
The difference in the results obtained with quartz and tridymite is difficult to explain: it might, however, be due to the number of particles per unit weight or to a difference in the surface state of the particles.

\section{Conclusion}

Mechanisms proposed to explain the carcinogen potency of some varieties of crystalline silica have been presented by Goldsmith et al. ${ }^{37}$

Two important facts must be pointed out in our experiment: firstly, quartz and tridymite did not give the same results. The level of SCEs was increased only in lymphocytes + monocytes treated with tridymite particles. Secondly, a cellular cooperation between lymphocytes and monocytes probably occurs and is necessary for the induction of SCEs by tridymite particles.

Damage of the genoma was observed in human lymphocytes treated with tridymite particles under certain conditions. Further experiments, however, are required to reach a conclusion about the genotoxic potency of crystalline silica.

We thank A Gaudichet (Laboratoire d'Etude des Particules Inhalées, Paris) for help, and $\mathrm{H}$ Daniel and P Sebastien (Centre d'Etudes et de Recherches des Charbonnages de France, Verneuil en Halatte) who supplied samples of silica.

1 International Agency for Research on Cancer. Monographs on the evaluation of the carcinogenic risk of chemicals to humans. Vol 42. Silica and some silicates. Lyon: IARC, 1987.

2 Katsnelson BA, Mokronosova KA. Non-fibrous mineral dusts and malignant tumours. An epidemiological study of mortality. J Occup Med 1979;21:15-20.

3 Armstrong B, McNulty J, Levitt LJ, Wiliams KA, Hobbs MST. Mortality in gold and coal miners in Western Australia with special reference to lung cancer. $B r J$ Ind Med 1989;36: 199-205.

4 Finkelstein $M$, Kusiak R, Suranyi G. Mortality among miners receiving workmen's compensation for silicosis in Ontario, 1940-1975. J Occup Med 1982;24:663-7.

5 Sherson D, Iversen E. Mortality among foundry workers in Denmark due to cancer and respiratory and cardiovascular disease. In: Goldsmith DF, Winn DM, Shy CM, eds. Silica, silicosis and cancer: controversy in occupational medicine. New York: Praeger, 1986:403-14

6 Fletcher AC. The mortality of foundry workers in the United Kingdom. In: Goldsmith DF, Winn DM, Shy CM, eds. Silica, silicosis and cancer: controversy in occupational medicine. New York: Praeger, 1986:385-402.

7 Schüler G, Rüttner JR. Silicosis and lung cancer in Switzerland. In: Goldsmith DF, Winn DM, Shy CM, eds. Silica, silicosis and cancer: controversy in occupational medicine. New York: Praeger, 1986:357-66.

8 Neuberger M, Kundi M, Westphal G, Gründerfer W. The Viennese dusty worker study. In: Goldsmith DF, Winn DM, Shy CM, eds. Silica, silicosis and cancer: controversy in occupational medicine. New York: Praeger, 1986:415-22.

9 Silverstein M, Maizlish N, Park R, Silverstein B, Brodsky L, Mirer F. Mortality among ferrous foundry workers. Am J Ind Med 1986;10:27-43.

10 Steenland $\mathrm{K}$, Beaumont J. A proportionate mortality study of granite cutters. Am J Ind Med 1986;9:189-201.

11 Forastiere F, Lagorio S, Michelozzi P, et al. Silica, silicosis and lung cancer among ceramic workers: a case-referent study. $\mathrm{Am}$ $J$ Ind Med 1986;10:363-70.

12 Zambon P, Simonato L, Mastrangelo G, Winkelmann R, Saia B, Crepet M. Mortality of workers compensated for silicosis during the period 1959-1963 in the Veneto region of Italy. Scand J Work Environ Health 1987;13:118-23.

13 Koskela RS, Klockars M, Jarvinen E, Kolari P, Rossi A. Mortality and disability among granite workers. Scand JWork Environ Health 1987;13:18-25.
14 Wagner MMF, Wagner JC. Lymphomas in the Wistar rat after intrapleural inoculation of silica. J Natl Cancer Inst 1972; 49:81-91.

15 Wagner MMF. Pathogenesis of malignant histiocytic lymphoma induced by silica in a colony of SPF Wistar rats. J Natl Cancer Inst 1976;57:509-14.

16 Wagner MMF, Wagner JC, Davies R, Griffiths DM. Silicainduced malignant histiocytic lymphoma: incidence linked with strain of rat and type of silica. Br J Cancer 1980;41: 908-17.

17 Jaurand MC, Fleury J, Monchaux G, Nebut M, Bignon J. Pleural carcinogenic potency of mineral fibers (asbestos, attapulgite) and their cytotoxicity on cultured cells. J Natl Cancer Inst 1987;79:797-804

18 Dagle GE, Wehner AP, Clark ML, Buschbom RL. Chronic inhalation exposure of rats to quartz. In: Goldsmith DF, Winn DM, Shy CM, eds. Silica, silicosis and cancer: controversy in occupational medicine. New York: Praeger, 1986:255-66.

19 Holland LM, Wilson JS, Tillery MI, Smith DM. Lung cancer in rats exposed to fibrogenic dusts. In: Goldsmith DF, Winn DM, Shy CM, eds. Silica, silicosis and cancer: controversy in occupational medicine. New York: Praeger, 1986:267-80.

20 Groth DH, Stettler LE, Platek SF, Lal JB, Burg JR. Lung tumours in rats treated with quartz by intratracheal instillation. In: Goldsmith DF, Winn DM, Shy CM, eds. Silica, silicosis and cancer: controversy in occupational medicine. New York: Praeger, 1986:243-54

21 Price-Jones M, Gubbings G, Chamberlain M. The genetic effects of crocidolite asbestos: comparison of chromosome abnormalities and sister-chromatid exchanges. Mutat Res 1980;79:331-6.

22 Oshimura M, Hesterberg TW, Tsutsui T, Barrett JC. Correlation of asbestos-induced cytogenetic effects with cell transformation of Syrian hamster embryo cells in culture. Cancer Res 1984;44:5017-22.

23 Hesterberg TW, Barrett JC. Dependence of asbestos and mineral dust induced transformation of mammalian cells in culture on fiber dimension. Cancer Res 1984:44:2170-80.

24 Hesterberg TW, Oshimura M, Brody AR, Barrett JC. Asbestos and silica induce morphological transformation of mammalian cells in culture: a possible mechanism. In: Goldsmith DF Winn DM, Shy CM, eds. Silica, silicosis and cancer: controversy in occupational medicine. New York: Praeger, 1986:177-90.

25 Dutrillaux B, Couturier J. La pratique de l'analyse chromosomique. Paris: Masson, 1981.

26 Jaurand MC, Renier A, Van der Meeren A, Magne L, Pinchon $\mathrm{MC}$, Bignon J. In vitro growth characteristics of rat mesothelioma cells in culture, Biol Cell 1986;57:249-56.

27 Sinha AK, Linscombe A, Gollapudi B, McClintock ML, Flake RE, Bodner KM. The incidence of spontaneous cytogenetic aberrations in lymphocytes cultured from normal humans for 48h and 62h. Can J Genet Cytol 1984;26:528-31.

28 Stanton MF, Layard M, Tegeris A, Miller E, May M, Kent E Carcinogenicity of fibrous glass: pleural response in the rat in relation to fiber dimension. J Natl Cancer Inst 1977;58: 587-603.

29 Harington JS. Fiber carcinogenesis: epidemologic observations and the Stanton hypothesis. J Natl Cancer Inst 1981;67: $977-89$.

30 Allison AC, Harington JS, Birbeck M. An examination of the cytotoxic effects of silica on macrophages. J Exp Med 1966; $124: 141-54$.

31 O'Rourke EJ, Halstead SB, Allison AC, Platts-Mills TAE. Specific lethality of silica for human peripheral blood mononuclear phagocytes, in vitro. J Immunol Methods 1978;19: $137-51$.

32 Barhad B, Manolescu N, Simionecu N, Ciocnitu V. Changes concerning the external structure of peritoneal macrophages, due to the DQ-12 standard dust. Environ Res 1983;31:256-65.

33 Schmidt JA, Oliver CN, Lepe-Zuniga JL, Green I, Gery I. Silica-stimulated monocytes release fibroblast proliferation factors identical to Interleukin 1. J Clin Invest 1984;73: 1462-72.

34 Saffiotti $U$. The pathology induced by silica in relation to fibrogenesis and carcinogenesis. In: Goldsmith DF, W'inn DM, Shy CM, eds. Silica, silicosis and cancer: controzersy in occupational medicine. New York: Praeger, 1986:287-307.

35 Kelsey KT, Nagasawa H, Umans RS, Little JB. Epidermal growth factor induces cytogenetic damage in mammalian cells. Carcinogenesis 1987;8:625-7.

36 Emerit I. Chromosome breakage factors: origin and possible significance. In: Natarajan AT, et al, eds. Progress in mutation research. Vol 4. Amsterdam: Elsevier, 1982:61-74.

37 Goldsmith DF, Guidotti TL, Johnston DR. Does occupational exposure to silica cause lung cancer? Am J Ind Med 1982; 3:423-40.

Accepted 13 March 1989 